Щипанський П. В., канд. військ. наук, професор ${ }^{1}$

(0000-0002-0854-733X)

Саганюк Ф. В., канд. юрид. наук., доцент ${ }^{2}$

1 - Національний університет оборони України імені Івана Черняховського, Київ;

2 - Центр воєнно-стратегічних досліджень Національного університету оборони України імені Івана Черняховського, Київ

\title{
Оборонний менеджмент: підходи до управління процесами оборонного планування
}

Резюме. Розглянуті можливі підходи до управління процесами оборонного планування.

Ключові слова: Збройні Сили України; модель; оборонний менеджмент; оборонне планування; сили оборони; спроможності.

Постановка проблеми. Державна політика у воєнній сфері, сферах оборони i військового будівництва нині спрямовується на створення сучасних, мобільних i боєздатних сил оборони, які користуватимуться повагою в суспільстві та в іноземних партнерів i міжнародних організацій, а також спільно 3 іншими інституціями держави забезпечуватимуть всеохоплюючу оборону України, захист іiі суверенітету, територіальної цілісності та недоторканності.

Базовими документами у цих сферах, окрім Стратегії національної безпеки України, Стратегії воєнної безпеки України та Стратегічного оборонного бюлетеня України, розроблених за результатами оборонного огляду фахівцями Департаменту воєнної політики та стратегічного планування Міністерства оборони України, Генерального штабу Збройних Силах України, інших військових структур, зокрема і Центру воєнностратегічних досліджень Національного університету оборони України імені Івана Черняховського, є низка методологічних i методичних керівних документів, серед яких: Доктрина 3 оборонного планування у Збройних Силах України, затверджена Головнокомандувачем Збройних Сил України 13.11.2020; Порядок організації та здійснення оборонного планування в Міністерстві оборони України, Збройних Силах України та інших складових сил оборони, затверджений наказом Міністерства оборони України від 22.12.2020 № 484; Положення про особливості організації освітнього процесу у вищих військових навчальних закладах Міністерства оборони України та військових навчальних підрозділах вищих навчальних закладів
України, затверджене наказом Міністерства оборони України від 20.07.2015 № 346 та ін.

У цих нормативно-правових актах зазначено, що оборонне планування в Україні здійснюється 3 метою забезпечення обороноздатності держави шляхом визначення пріоритетів і напрямів розвитку сил оборони.

Водночас у цих документах обгрунтовані й основні ймовірні ризики у сфері воєнної безпеки і оборони, серед яких:

ухвалення стратегічно помилкових рішень у воєнній сфері, сфері оборони i військового будівництва на підставі неякісного аналізу реальних i потенційних воєнних загроз національній безпеці;

неефективний розподіл видатків на оборону України та витрачання державних ресурсів на утримання безперспективного озброєння, військової та спеціальної техніки;

недостатня спроможність забезпечити відсіч і стримування збройної агресії з боку Російської Федерації традиційними формами і способами збройної боротьби;

недостатній рівень взаємодії та неузгодженість заходів, які здійснюються силами оборони, іншими складовими сектору безпеки і оборони;

недостатні спроможності Збройних Сил України та інших складових сил оборони щодо охорони повітряного простору та протиповітряного прикриття важливих державних і військових об'єктів, недостатні військово-морські спроможності, зокрема щодо охорони підводного простору в межах територіального моря України, берегової оборони та захисту національних інтересів України в Азовському і Чорному морях;

нездатність провести весь комплекс заходів стратегічного розгортання у короткі строки в разі ескалації воєнного конфлікту або 
повномасштабної збройної агресії Російської Федерації проти України тощо.

Одним із пріоритетів i завдань вирішення вказаних проблем сучасності Стратегією воєнної безпеки України визначений ефективний менеджмент у сфері оборони, заснований на засадах демократичного цивільного контролю, інших євроатлантичних принципах i стандартах, інноваційних рішеннях і сучасних практиках, програмно-проєктному управлінні оборонними ресурсами, а також на удосконалених процесах визначення та задоволення сучасних потреб оборони України [1].

Важливим завданням наукової діяльності у цій сфері є формування сучасного наукового кадрового потенціалу, здатного забезпечити розвиток наукового прогресу у військовій галузі. Належне виконання цього завдання забезпечують система підготовки науково-педагогічних і наукових кадрів.

У наукових публікаціях [2-14] обгрунтовано різні моделі та необхідність підвищення в умовах сьогодення ефективності оборонного менеджменту 3 управління процесами оборонного планування, передусім забезпечувального характеру, для досягнення визначених стратегічних цілей оборонної реформи та наближення цих процесів до стандартів, прийнятих в арміях держав членів НАТО.
Аналіз останніх досліджень i публікацій. У літературі розкриті різні моделі менеджменту підходи до управління процесами оборонного планування. Зокрема, у [2-4] йдеться про моделі менеджменту як форми управління практичними діями для досягнення бажаного результату. В інших публікаціях розглядаються теоретичні та прикладні моделі, що дає змогу оцінити параметри функціонування конкретного об’єкта i сформулювати відповідні рекомендації для прийняття практичних рішень. У [5-9] йдеться про імплементаційну практику та інші управлінські процеси.

Автори [10] виклали підходи до можливої імплементації норм чинного Закону України "Про національну безпеку України", пов'язані 3 формуванням сучасної системи оборонного планування та розвитку сектору безпеки і оборони, розробленням довго- та середньострокових документів стратегічного та оборонного планування розвитку військ (сил) на основі спроможності за базовими складовими DOTMLPFI, яка широко застосовується в арміях держав - членів НАТО. Серед них наказом Міністерства оборони України від 22.12.2020 № 484 визначені доктринальна база, організація, підготовка, ресурсне забезпечення, якість управління та освіта, персонал, військова інфраструктура, взаємосумісність, які у сукупності $\epsilon$ визначальними для утворення та досягнення спроможності в цілому (рис. 1).

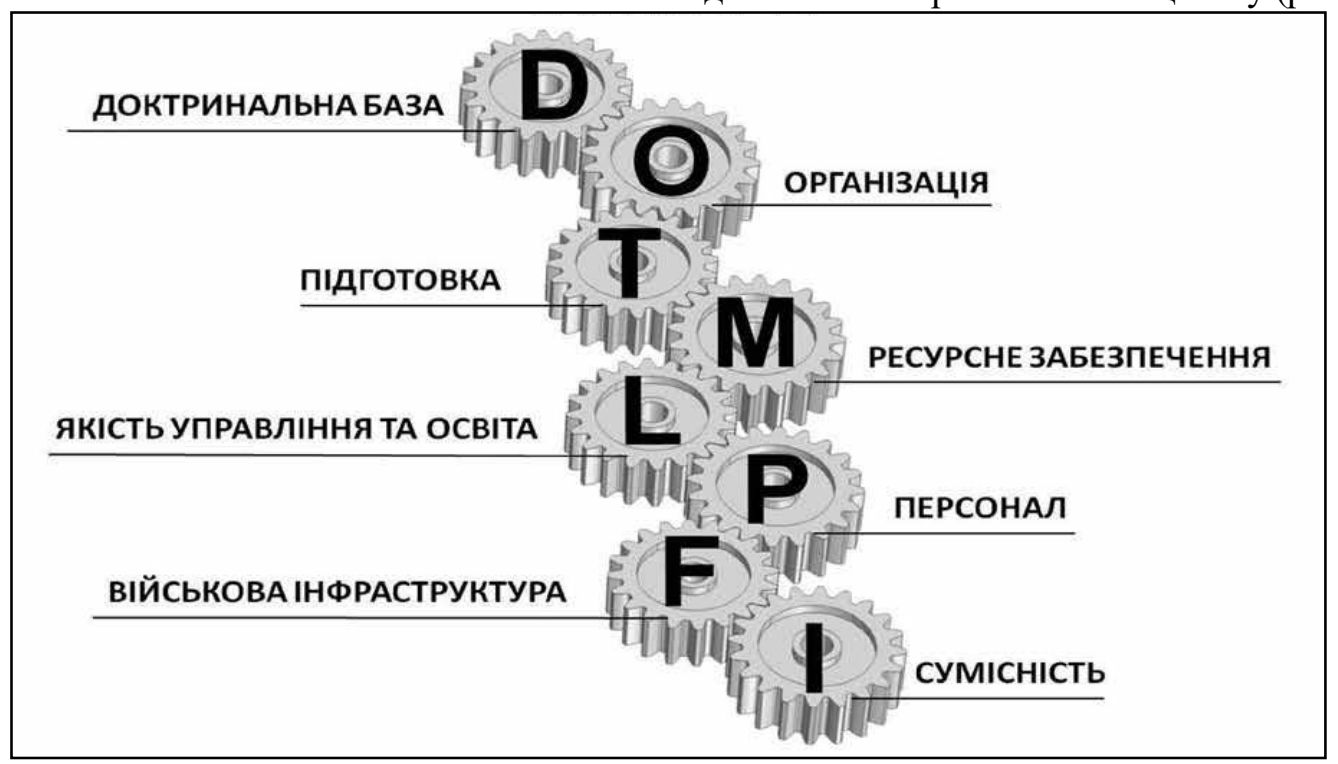

Рис. 1. Базові складові спроможності (DOTMLPFI)

В оборонному менеджменті під час управління процесами оборонного планування основним $є$ досягнення визначених стратегічних цілей на найближчу та віддалену перспективи через всебічне нормативно- правове, організаційне, методичне, ресурсне та інше необхідне забезпечення ефективності всіх управлінських процесів [13].

Управляти такою діяльністю, як стверджував французький дослідник Анрі 
Файоль, - це прогнозувати, планувати, організовувати, командувати, координувати i контролювати іiі [3].

Отже, 3 аналізу наведених та інших публікацій цього напряму дослідження можна дійти висновку про необхідність пошуку ефективних підходів до формування сучасної моделі управління процесами оборонного планування, що й обумовлює мету цієї статті.

Метою статті $\epsilon$ пошук ефективних підходів до формування сучасної моделі управління процесами оборонного планування, наближення їх до сучасних потреб Збройних Сил, а також принципів i стандартів, прийнятих в арміях розвинутих держав - членів НАТО.

Викладення основного матеріалу. Загальна методологія оборонного менеджменту в процесі оборонного планування в Міністерстві оборони України та Збройних Силах України нині визначена згаданим вище наказом Міністерства оборони України, згідно 3 яким на структурні підрозділи Міністерства оборони України в межах їх компетенції покладаються такі основні завдання:

аналіз воєнно-політичної обстановки та визначення рівня загроз національній безпеці України у воєнній сфері;

підготовка пропозицій до основних документів щодо формування та реалізації державної політики 3 питань національної безпеки і оборони;

визначення пріоритетів, основних напрямів розвитку Збройних Сил України та інших складових сил оборони;

розроблення Стратегії воєнної безпеки України і Стратегічного оборонного бюлетеня України;

участь у розробленні та моніторинг виконання програм і планів діяльності Кабінету Міністрів України;

організація розроблення проєктів державних цільових програм, моніторинг їх виконання;

організація досліджень 3 питань оборонного планування;

участь у підготовці пропозицій до прогнозів видатків 3 державного бюджету на сили оборони; формування бюджетного запиту Міністерства оборони України; формування основних показників Міністерства оборони України як державного замовника для здійснення оборонних закупівель;

контроль за ефективним витрачанням коштів і матеріальних цінностей;

підготовка звітних матеріалів про використання коштів, виділених на потреби оборони;

інформаційне забезпечення оборонного планування.

Зважаючи на наказ Міністерства оборони України від 22.12.2020 № 484, процес оборонного планування, включає:

планування спроможностей;

програмування

розвитку спроможностей;

бюджетування та управління ресурсами; виконання програм і планів.

Імплементуючи положення зазначених концептуальних документів, загальний алгоритм оборонного менеджменту, а саме 3 управління процесами оборонного планування, можна представити схематично (рис. 2).

Планування спроможностей на довгострокову перспективу полягає у визначенні основних напрямів реалізації воєнної політики, стратегічних цілей розвитку та очікуваних результатів їх досягнення 3 урахуванням актуальних викликів i загроз національній безпеці України у воєнній сфері.

Під час планування спроможностей:

1) проводять аналіз майбутнього безпекового середовища;

2) розробляють імовірні сценарії виникнення та розвитку ситуацій воєнного характеру і варіантів застосовування Збройних Сил України та інших складових сил оборони;

3) розробляють об’єднану оперативну концепцію;

4) визначають вимоги до спроможностей сил оборони (переліки завдань, необхідних, наявних, критичних та надлишкових спроможностей);

5) формують перспективну модель сил оборони 3 урахуванням прогнозу ресурсного забезпечення сил оборони. 


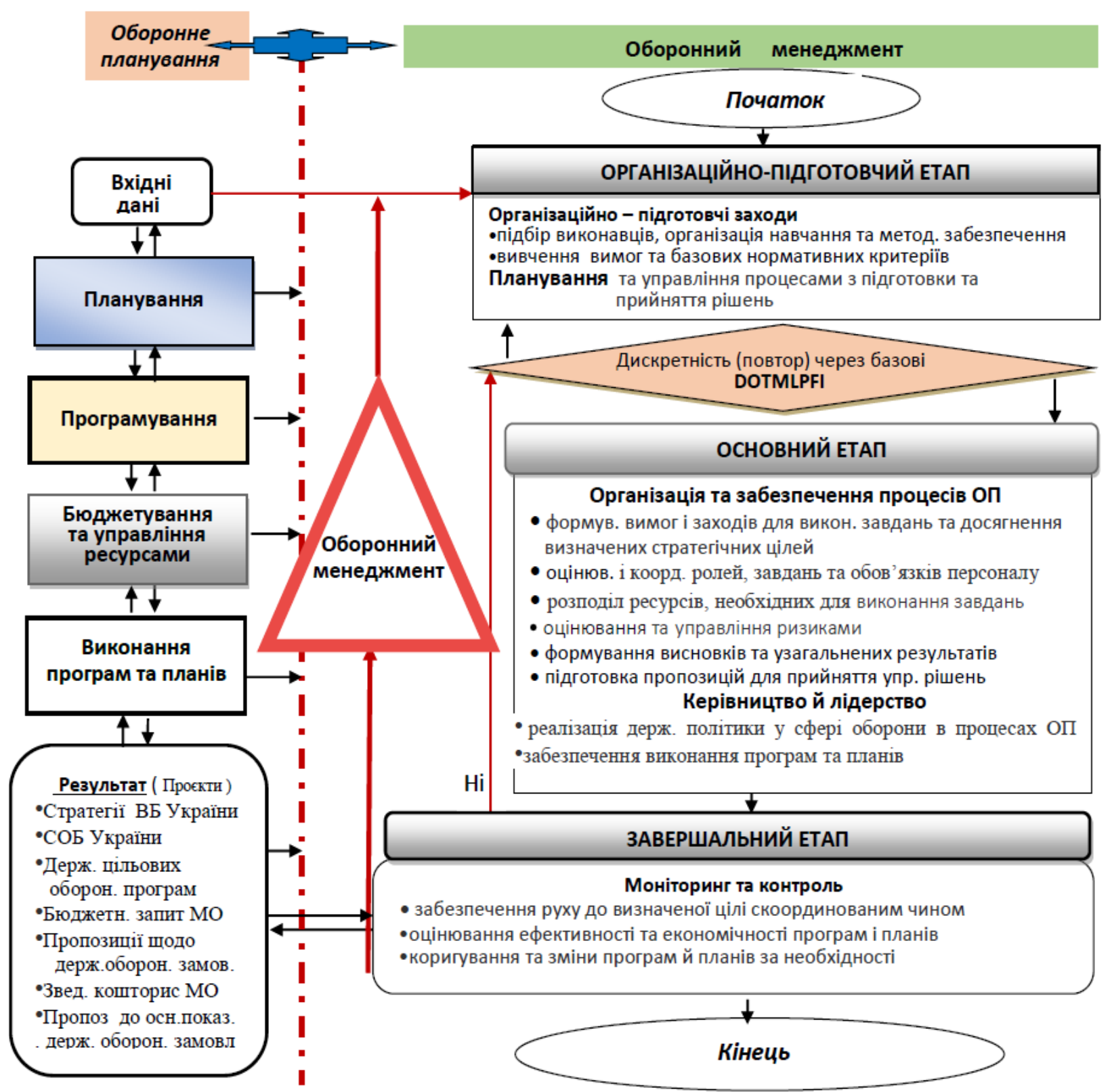

Рис. 2. Варіант алгоритму управління процесами оборонного планування

Програмування розвитку спроможностей на середньострокову перспективу полягає у деталізації завдань i заходів, спрямованих на досягнення цілей та очікуваних результатів розвитку складових сил оборони і передбачає розроблення:

державних цільових програм, спрямованих на розв'язання проблем забезпечення оборони держави та розвиток складових сил оборони, зокрема їх оснащення сучасним озброєнням і військовою технікою, створення необхідних запасів матеріальнотехнічних засобів, реалізацію інших заходів 3 посилення обороноздатності держави (далі державні цільові оборонні програми);

комплексів програм (проєктів), спрямованих на створення нових, розвиток існуючих i позбавлення від надлишкових спроможностей Міністерства оборони України, Збройних Сил України та інших складових сил оборони.

Державні цільові програми складових сил оборони розробляються відповідно до Закону України від 18.03.2004 № 1621-IV (зі змінами та доповненнями) з урахуванням:

завдань i пріоритетів, визначених Стратегічним оборонним бюлетенем України; викликів і загроз воєнного характеру, що впливають на рівень воєнної безпеки i оборони;

імовірних сценаріїв виникнення та розвитку ситуацій воєнного характеру;

параметрів перспективної моделі, структури та чисельності складових сил оборони і потреби для їх досягнення; 
обсягів прогнозованого ресурсного забезпечення складових сил оборони;

порядку досягнення необхідних спроможностей складових сил оборони за всіма ї базовими складовими iз застосуванням матеріальних і нематеріальних рішень на всіх етапах життєвого циклу спроможності.

Комплекс програм (проєктів) розвитку спроможностей складових сил оборони передбачає розроблення їх за методологією програмно-проєктного менеджменту.

Бюджетування та управління ресурсами спрямовується на забезпечення виконання завдань 3 реалізації державної політики у сфері оборони на короткострокову перспективу 3 урахуванням процедур i термінів бюджетного процесу [13]. Цей процес передбачає розроблення:

орієнтовних планів та планів утримання і розвитку складових сил оборони;

планів утримання та розвитку видів, окремих родів військ (сил);

основних показників закупівель товарів, робіт i послуг оборонного призначення за закритим форматом (на трирічний період);

підготовку бюджетних запитів i формування кошторисів Міноборони та інших складових сил оборони.

Процес бюджетування та управління ресурсами здійснюється 3 урахуванням військово-політичних вказівок, які розробляються у місячний строк після затвердження Державного бюджету України та затверджуються наказом Міністерства оборони України (органів державної влади) до сфери управління (координації) яких віднесені відповідні складові сил оборони.

Визначення необхідного ресурсного забезпечення складових сил оборони включає [13]:

формування орієнтовної потреби в персоналі, інвестиціях на озброєння, військову і спеціальну техніку та системи вітчизняного й іноземного виробництва, інфраструктуру; експлуатаційних витратах для набуття силами оборони необхідних спроможностей;

формулювання вимог до вітчизняного оборонно-промислового комплексу щодо можливостей розроблення (модернізації) i виробництва основних зразків озброєння та військової техніки, 3 огляду на ймовірні сценарії, завдання за ними, необхідні спроможностей для виконання цих завдань та відповідний склад сил;

прогноз набуття спроможностей складових сил оборони залежно від обсягів фінансування, можливостей вітчизняного оборонно-промислового комплексу та закупівлі озброєння й військової техніки іноземного виробництва.

За кожним варіантом розрахунків визначення та розподілу потреб в основних зразках виробів озброєння та військової техніки розраховується показник рівня виконання завдань за сценаріями (очікуваний рівень досягнення спроможностей), необхідна частка витрат на розвиток озброєння та військової техніки від загальної суми видатків, прогноз співвідношення щодо закупівлі техніки вітчизняного та іноземного виробництва, очікуваний рівень оновлення основних зразків виробів озброєння та військової техніки на кінець планового періоду.

Проведені розрахунки ресурсних потреб i визначені альтернативи досягнення мінімально-необхідного рівня виконання завдань 3 оборони держави використовуються під час формування перспективної моделі Збройних Сил України та інших складових сил оборони.

Розроблення проєкту військовополітичних вказівок здійснює структурний підрозділ апарату Міністерства оборони України, на який покладено функції визначення засад воєнної політики та стратегічного планування (відповідний структурний підрозділ органу державної влади, до сфери управління (координації) якого належать інші складові сил оборони).

Управління прочесом виконання (реалізаціi) цілей, завдань і планових заходів розвитку спроможностей Збройних Сил України та інших складових сил оборони здійснюється колегіальним органом Міністерства оборони України (інших складових сил оборони), який утворюється 3 метою:

визначення пріоритетів розвитку Збройних Сил України та інших складових сил оборони;

розроблення проєктів концепцій, стратегій і програмних документів розвитку Збройних Сил України та інших складових сил оборони;

управління змінами під час реалізації програм (проєктів) розвитку спроможностей Збройних Сил України та інших складових сил оборони.

Процес виконання програм і планів включає:

управління програмами (проєктами) розвитку спроможностей; 
проведення оцінювань спроможностей; моніторинг i контроль виконання заходів оборонного планування;

управління ризиками;

звітування про виконання програм i планів.

Методологічно, за змістовною ознакою, менеджмент 3 управління процесами класифікують як нормативний, стратегічний, оперативний [4]. Нормативний менеджмент спрямовується на створення доктринальних (нормативно-правових) основ реалізації місії певної діяльності та визначеної цілі за відповідними стандартами для формування загальної моделі й стратегії дій.

Стратегічний менеджмент охоплює розроблення такої стратегії для всіх складових та підрозділів організації, розподіл завдань щодо реалізації вибраної стратегії за часом. Він формує потенціал успіху й забезпечує загальний контроль за цим процесом.

Оперативний менеджмент розробляє методи реалізації прийнятої моделі та стратегії в конкретних умовах, тактичною адаптацією та оперативним реагуванням на умови, що змінюються.

Законом України "Про національну безпеку України” (п. 12 ст. 1) оборонне планування визнано складовою частиною системи державного стратегічного планування, що здійснюється 3 метою забезпечення обороноздатності держави шляхом визначення пріоритетів i напрямів розвитку сил оборони, їх спроможностей, озброєння та військової техніки, інфраструктури, підготовки військ (сил), а також розроблення відповідних концепцій, програм i планів 3 урахуванням реальних i потенційних загроз у воєнній сфері та фінансово-економічних можливостей держави. Виявляється, що ці правові засади мають бути імплементовані у зазначеній моделі. Указана проблема ще дискутується.

На думку авторів наукових публікацій [9-14], найбільш актуальними та складними у контексті імплементації на перспективу $\epsilon$ норми Закону України "Про національну безпеку України”, пов’язані 3 формуванням сучасної системи планування у сферах національної безпеки і оборони, розвитком сектору безпеки і оборони, розробленням та затвердженням за результатами оборонного огляду низки важливих довго- та середньострокових документів оборонного планування.
Висновки. 3 огляду на сучасну воєнностратегічну ситуацію, способи та методи ведення РФ агресивної гібридної війни проти України, оборонне планування розвитку та застосування Збройних Сил України на сучасному етапі потребує істотного вдосконалення, посилення оборонного менеджменту, зокрема управління його процесами, приведення їх до сучасних потреб та світового досвіду, передусім до принципів і стандартів, прийнятих в арміях державчленів НАТО.

Для цього, як визначено Стратегією воєнної безпеки України, у сфері оборони, зокрема в процесі оборонного планування, необхідно здійснювати ефективний менеджмент, заснований на засадах демократичного цивільного контролю, інших євроатлантичних принципах i стандартах, інноваційних рішеннях та сучасних практиках, програмно-проєктному управлінні оборонними ресурсами, а також на удосконалених процесах визначення та задоволення потреб оборони України.

Кінцевим результатом процесу такого оборонного планування $€$ раціональні управлінські рішення у формі концепцій, стратегій, програм і планів щодо реалізації державної політики 3 питань національної безпеки і оборони у воєнній сфері, сферах оборони i військового будівництва, які, зважаючи на фінансово-економічні можливості держави, забезпечують досягнення рівня обороноздатності держави, необхідного для протидії наявним та можливим майбутнім викликам i загрозам воєнного характеру.

Відповідальність за моніторинг і контроль виконання цих стратегічних положень 3 оборонного планування та оборонного менеджменту в Міноборони та Збройних Силах покладається на керівників структурних підрозділів Міноборони та Генерального штабу, командувань видів, окремих родів військ (сил) та інших органів військового управління за напрямами діяльності, відповідальних за функціональні групи спроможностей, а в інших складових сил оборони - на відповідних керівників.

Напрям подальших досліджень. Для якісної підготовки та ефективного оборонного менеджменту 3 управління процесами оборонного планування доцільно наблизити ці процеси до принципів і стандартів, прийнятих в арміях держав - членів НАТО. 


\section{СПИСОК ВИКОРИСТАНОЇ ЛІТЕРАТУРИ}

1. Про рішення Ради національної безпеки i оборони України від 25.03.2021 р. "Про Стратегію воєнної безпеки України” : Указ Президента України від 25.03.2021 № 121/2021.

2. Ачкасов А. Є., Воронков О. О. Конспект лекцій з курсу "Економіко-математичне моделювання". Харіків : ХНАМГ, 2011. 204 с.

3. История менеджмента : уч. пособ. / под ред. Д. В. Валового. Москва : ИНФРА, 1997. С. 218220.

4. Рульєв В. А., Гуткевич С. О. Менеджмент : навч. посіб. Київ : Центр учбової літератури, 2011. $312 \mathrm{c.}$

5. Клименко О. Базові засади імплементації міжнародних нормативних документів у діяльності наукових бібліотек України: термінологічний аспект. URL: http://nbuviap.gov.ua/ index.php? option=com (дата звернення: 04.01.2021).

6. Руснак I. C., Петренко А. Г., Яковенко А. В., Романюк I. М., Кохно В. Д. Оборонне планування на основі спроможностей: особливості та перспективи впровадження. Наука $i$ оборона. 2017. № 2. C. 3-10.

7. Петренко А. Г. Щодо впровадження оборонного менеджменту та управління змінами в Міністерстві оборони України. Наука і оборона. 2019. № 2. C. 3-8.

8. Романченко I. С., Богданович В. Ю., Дєнєжкін М. М. Теоретико-методологічні засади побудови системи управління ефективністю планування та виконання програм розвитку
Збройних Сил України. Наука $і$ оборона. 2015. № 3-4. С. 50-55.

9. Тютюнник В. П., Лобко М. М. План оборони України: проблеми та рекомендації щодо визначення структури цього нового документа. Виклики та ризики. Безпековий огляд Центру дослідження армії, конверсії та роззброєння : аналіт. бюлет. 2019. № 19 (130). С. 10-21.

10. Щипанський П. В., Мобілізаційний резерв як фактор збільшення можливостей національної економіки задовольнити потреби Збройних Сил України. Збірник наукових праць Центру воєнностратегічних досліджень Національного університету оборони України імені Івана Черняховського. Київ, 2019. № 2 (66). С. 22-28.

11. Горовенко В. План оборони України: у зоні особливої уваги. Defense express. 2019. 24 жовтня.

12. Тютюнник В. П., Горовенко В. К. Як імплементувати Закон України "Про національну безпеку України". Defense Express. 2018. 6 вересня.

13. Порядок організації та здійснення оборонного планування в Міністерстві оборони України, Збройних Силах України та інших складових сил оборони : затв. наказом Міністерства оборони України від 22.12.2020 р. № 484.

14. Оборонна реформа: системний підхід до оборонного менеджменту : монографія / А. Павліковський, В. Фролов, Ф. Саганюк, Ю. Мудрак та ін.; за заг. ред. д-ра військ. наук А. Сиротенка. Київ : НУОУ, 2020. 276 с.

Стаття надійшла до редакційної колегії 01.02.2021

\section{Defense management: approaches to managing defense planning processes}

\section{Annotation}

State policy in the military sphere, defense and military construction is now aimed at creating modern mobile and combat-ready defense forces that will be respected in society and by foreign partners and international organizations, together with other state institutions will ensure comprehensive defense of Ukraine, protection of its sovereignty and territory integrity and inviolability.

Numerous scientific publications substantiate various models and the need to increase the effectiveness of defense management in the current environment of managing defense planning processes, especially security, in order to achieve certain strategic goals of defense reform and bring these processes closer to standards adopted in NATO armies.

The purpose of the article is to find effective approaches to the formation of a model for managing defense planning processes, bringing them closer to modern needs and the principles and standards adopted in the armies of developed NATO member states.

Defense planning is carried out in order to ensure the state's defense capabilities by determining the priorities and directions of development of defense forces, their capabilities, armaments and military equipment, infrastructure, training of troops (forces), as well as developing appropriate concepts, programs and plans taking into account real and potential threats in military sphere and financial and economic capabilities of the state. It is carried out using the capability-based planning method, which aims to develop them in the long term.

The defense planning process includes: capability planning; capacity development programming; budgeting and resource management; implementation of programs and plans.

In order to qualitatively prepare and implement effective defense management for the management of defense planning processes, it is expedient to improve the methodology of this work in practice, to bring these processes closer to the principles and standards adopted in the armies of NATO member states.

Keywords: Armed Forces of Ukraine; model; defense management; defense planning; defense forces; capabilities. 